\title{
Comparative Performance of Different Genotypes of Peach Based on their Rooting Response of Hardwood Cuttings
}

\author{
Shashank Kumar*, Samik Sengupta, Neha Nandan, Arun Kumar and Prem Prakash
}

Department of Horticulture, Bihar Agricultural University, Sabour, Bhagalpur, Bihar-813210, India

*Corresponding author

\section{A B S T R A C T}

\section{Keywords}

Genotypes, Hardwood cuttings, Callusing, Reserve food materials, Internal free-auxin

Article Info

Accepted:

12 April 2018 Available Online: 10 May 2018
Present investigation consisted of hardwood cuttings of about $15-20 \mathrm{~cm}$ length and 0.8 $1.2 \mathrm{~cm}$ diameter having 5-6 buds that were prepared from the dormant twigs of the 4-5 years old peach plants in the second fortnight of November. The basal portion of the cuttings was dipped in different doses of nine treatments viz. IBA (1500 ppm, and 3000 ppm), NAA (1000 ppm, and $2000 \mathrm{ppm}$ ) and combinations of IBA and NAA (IBA 1500 ppm + NAA 1000 ppm, IBA 1500 ppm + NAA 2000 ppm, IBA 3000 ppm + NAA 1000 ppm and IBA 3000 ppm + NAA 2000 ppm) and control were evaluated. On the basis of data recorded on rooting parameters after 45 days of planting, it was concluded that rooting parameters like root length, root thickness, length of main root, number of roots/cutting and root weight were found maximum in Early Grande when treated with IBA 3000ppm. It was concluded that IBA at $3000 \mathrm{ppm}$ was found to be the best treatment for propagation of peach through hardwood cuttings.

\section{Introduction}

Peach (Prunus persica L.) belongs to the family Rosaceae, originated from China, is a diploid species $(2 n=16)$. It is one of the temperate regions fruit crop having a medium stature upto $8 \mathrm{~m}$. It is classified as a stone fruit species. Besides being cultivated in the temperate climate in the hills, it is also cultivated in the North Indian plains (subtropical climate) in the states of Punjab, Haryana, Rajasthan and Uttar Pradesh with the introduction of low chilled peaches. The subtropical peaches come in the market early in season (mid-April), growers can get higher returns due to scarcity of other fresh fruits. Its first commercial crop is obtained within three years of planting which is much earlier than majority of other temperate fruits. Peach trees are generally grown for commercial production as two genetically different components consisting of a scion either budded or grafted to a rootstock. But it can be clonally propagated through rooting of hardwood cutting. Propagation from cuttings (cloning) produces a plant with the same characteristics as the parent and thus maintains desirable fruiting traits. In comparison with other types of cuttings (semi-hardwood, softwood and so on) hardwood cuttings are easy to take, handle, and store which allows for flexibility in the preparation of the cutting 
and in general, less precision than cuttings that include actively growing tissue (Hartmann et al., 2002). Hardwood cuttings are one of the least expensive and easiest methods of vegetative propagation. They are easy to prepare, are not readily perishable, may be shipped safely over long distances if necessary and require little or no special equipment during rooting (Denny and Arnold, 2001).

Hardwood cuttings are most often used in propagation of deciduous woody plants (Hartmann et al., 2002) as one of the most simple, non-toxic, cheapest and easiest methods of vegetative propagation. It is important, particularly in horticulture for mass production of improved materials with in short time and to perpetuate the characteristics of the parent plant (Hartmann and Kester, 1983). Moreover, Indole-3-butyric acid is probably the best material for general use, because it is non-toxic to plants over a wide concentration range and is effective in promoting rooting of a large number of plant species (Hartmann and Kester, 1990). The most successful results have been obtained from IBA treatments including auxin hormone group. IBA has been found to be critical for both softwood and hardwood cuttings (Erdoan and Aygun, 2006; Tworkoski and Takeda, 2007). As some varities of Peach (Shan-i-Punjab, Pratap, Prabhat, Florda Prince and Early Grande) are available in Bihar and these are well responding in terms of fruiting. But its cultivation is limited in BAU, Sabour only due to lack of its planting material. So, the objective of present investigation is to prepare planting material through rooting of cutting of available genotypes of Peach, so that in coming scenario Peach fruit would be available in our Bihar's market and hence farmers could get extra income. The present investigation was carried out to study the rooting ability of hardwood cuttings of different genotypes of peach under subtropical condition of Bihar.

\section{Materials and Methods}

The experiment was carried out in the Horticulture Garden, Bihar Agricultural College, Sabour, Bhagalpur, Bihar during 2016-17, on plants that were planted in 02-032012 (4 year) behind the Agricultural Farm of Bihar Agriculture College, Sabour. All the trees were maintained under uniform cultural practices during the course of investigation. Hard wood cuttings of $15-20 \mathrm{~cm}$ length and $0.8-1.2 \mathrm{~cm}$ in diameter having 5-6 buds were prepared from dormant twigs.

The basal portion of the cuttings was dipped in different doses of Indole-3-butyric acid IBA (1500ppm and 3000ppm), NAA (1000ppm and 2000ppm) and IBA and NAA combinations for 10sec. After that the cuttings were planted in root trainer and then kept in mist chamber $\left(18-20^{\circ} \mathrm{C}\right)$ at a spacing of $7 \mathrm{~cm} \mathrm{X}$ $10 \mathrm{~cm}$, and then proper cultural practices were followed. After that data on rooting parameters like survival percentage, rooting percentage, root length, callusing percentage, root wt. etc. were recorded and analysed with Completely Randomized Block Design.

\section{Results and Discussion}

The days taken for rooting, average number of roots, length of main root, root weight, and root thickness were significantly influenced by different concentrations of IBA and NAA and their combinations.

\section{Root length, root thickness, length of main root, number of roots, root weight}

Number of roots/cutting was found highest (13.00) in Early Grande treated with IBA3000ppm followed by IBA-1500ppm (12.62). The increase in number of roots/cutting may be due to the effect of IBA as it increases cell wall plasticity and cell division, stimulates callus development and root growth (Weaver, 1972). IBA helps in mobilizing reserved food material, elongation of meristematic cells and 
differentiation of cambial initials into root primordia (Nanda, 1975). It appears probable that the success of IBA is due to its low auxin activity and its slow degradation by auxin destroying enzyme. Leopold (1995) suggested that IBA is quite a strong auxin, while NAA is readily destroyed. It is generally accepted that auxins play a central role in the process of root formation (Davis et al., 1989; De Klerk et al., 1999). For successful root induction, plants need to contain a certain quantity of IBA. It is common to use IBA for rooting of fruit type because it has a greater ability to promote adventitious root formation in comparison to IAA (Spethmann and Hamzah, 1988; Riov,
1993; De Klerk et al., 1999; Ludwig-Müller, 2000). It is more stable and less sensitive to the auxin degrading enzymes (Riov, 1993). The result of the present studies are in agreement with the findings of Rufato and Kersten (2000) in Esmeralda Peach, Swedan et al., (1993) in hardwood cuttings of plum, peach and GF677 peach rootstock, Tajbakhsh et al., (2009) and Iqbal et al., (1999) in apple cuttings, Sharma et al., (1991) in guava, Bal et al., (2000) in Plum, Ahmad et al., (2010), Mirabdulbaghi et al., (2011) in natural plumapricot hybrid, Ahmed et al., (2003) in peach rootstock, and Galavi et al., (2013) in grape cuttings (Table 1-6).

Table.1 Effect of different treatments on root length of cuttings $(\mathrm{cm})$ at 45 days

\begin{tabular}{|c|c|c|c|c|c|c|}
\hline \multicolumn{2}{|r|}{ Treatments } & \multirow{2}{*}{$\begin{array}{l}\text { Pratap } \\
4.65\end{array}$} & \multirow{2}{*}{$\begin{array}{l}\text { Prabhat } \\
4.15\end{array}$} & \multirow{2}{*}{$\begin{array}{c}\text { Shan-e- } \\
\text { Punjab } \\
8.17\end{array}$} & \multirow{2}{*}{$\begin{array}{c}\text { Florda Prince } \\
7.81\end{array}$} & \multirow{2}{*}{$\begin{array}{c}\text { Early } \\
\text { Grande } \\
9.10\end{array}$} \\
\hline $\mathrm{T}_{1}$ & IBA $1500 p p m$ & & & & & \\
\hline $\mathbf{T}_{2}$ & IBA 3000ppm & 5.00 & 4.55 & 8.51 & 8.23 & 9.48 \\
\hline$T_{3}$ & NAA 1000ppm & 3.80 & 3.40 & 7.32 & 6.85 & 8.60 \\
\hline $\mathbf{T}_{4}$ & NAA 2000ppm & 4.10 & 3.85 & 7.64 & 7.10 & 8.83 \\
\hline$T_{5}$ & IBA 1500+NAA 1000ppm & 2.60 & 2.30 & 5.70 & 5.33 & 6.89 \\
\hline$T_{6}$ & IBA $1500+$ NAA $2000 p p m$ & 2.30 & 2.00 & 5.20 & 4.87 & 6.37 \\
\hline $\mathbf{T}_{7}$ & IBA 3000+NAA 1000ppm & 3.40 & 3.00 & 6.48 & 5.95 & 7.62 \\
\hline $\mathrm{T}_{8}$ & IBA 3000+NAA 2000ppm & 3.00 & 2.65 & 5.94 & 5.80 & 7.31 \\
\hline$T_{9}$ & Control & 0.00 & 0.00 & 0.00 & 0.00 & 0.00 \\
\hline & S.E. $(\mathrm{m}) \pm$ & 0.09 & 0.10 & 0.19 & 0.08 & 0.33 \\
\hline & $\mathrm{CD}_{(\mathrm{P}=0.05)}$ & 0.25 & 0.31 & 0.56 & 0.23 & 1.00 \\
\hline & $\mathrm{CV}(\%)$ & 4.59 & 6.24 & 5.26 & 2.25 & 8.09 \\
\hline
\end{tabular}

Table.2 Effect of different treatments on root thickness of cuttings (mm) at 45 days

\begin{tabular}{|c|c|c|c|c|c|c|}
\hline \multicolumn{2}{|r|}{ Treatments } & \multirow{2}{*}{$\begin{array}{l}\text { Pratap } \\
2.05\end{array}$} & \multirow{2}{*}{$\begin{array}{c}\text { Prabhat } \\
1.65\end{array}$} & \multirow{2}{*}{$\begin{array}{c}\text { Shan-e-Punjab } \\
2.95\end{array}$} & \multirow{2}{*}{$\begin{array}{c}\text { Florda Prince } \\
2.85\end{array}$} & \multirow{2}{*}{$\begin{array}{c}\text { Early Grande } \\
3.04\end{array}$} \\
\hline $\mathrm{T}_{1}$ & IBA 1500ppm & & & & & \\
\hline $\mathrm{T}_{2}$ & IBA 3000ppm & 2.08 & 1.69 & 2.99 & 2.89 & 3.08 \\
\hline$\overline{T_{3}}$ & NAA 1000ppm & 1.93 & 1.21 & 2.73 & 2.63 & 2.82 \\
\hline $\mathrm{T}_{4}$ & NAA 2000ppm & 2.03 & 1.33 & 2.85 & 2.75 & 2.94 \\
\hline$T_{5}$ & IBA 1500+NAA 1000ppm & 0.85 & 0.73 & 1.43 & 1.33 & 1.55 \\
\hline$T_{6}$ & IBA 1500+NAA 2000ppm & 0.70 & 0.55 & 1.21 & 1.11 & 1.30 \\
\hline $\mathrm{T}_{7}$ & IBA 3000+NAA 1000ppm & 1.58 & 1.13 & 2.42 & 2.32 & 2.51 \\
\hline $\mathrm{T}_{8}$ & IBA $3000+N A A 2000 p p m$ & 1.25 & 0.86 & 2.00 & 1.90 & 2.10 \\
\hline $\mathrm{T}_{9}$ & Control & 0.00 & 0.00 & 0.00 & 0.00 & 0.00 \\
\hline & S.E. $(\mathrm{m}) \pm$ & 0.02 & 0.02 & 0.02 & 0.02 & 0.02 \\
\hline & $\mathrm{CD}_{(\mathrm{P}=0.05)}$ & 0.05 & 0.05 & 0.05 & 0.05 & 0.05 \\
\hline & CV (\%) & 2.15 & 2.84 & 1.35 & 1.56 & 1.46 \\
\hline
\end{tabular}


Table.3 Effect of different treatments on length of main root $(\mathrm{cm})$ of cuttings

\begin{tabular}{|c|c|c|c|c|c|c|}
\hline \multicolumn{2}{|r|}{ Treatments } & Pratap & Prabhat & Shan-e-Punjab & Florda Prince & Early Grande \\
\hline$T_{1}$ & IBA 1500ppm & 4.23 & 4.78 & 9.11 & 7.53 & 10.93 \\
\hline$\overline{\mathbf{T}_{2}}$ & IBA 3000ppm & 4.55 & 5.43 & 9.53 & 7.87 & 11.25 \\
\hline $\mathbf{T}_{3}$ & NAA 1000ppm & 3.26 & 3.85 & 8.27 & 6.91 & 10.17 \\
\hline $\mathbf{T}_{4}$ & NAA 2000ppm & 3.78 & 4.20 & 8.81 & 7.24 & 10.69 \\
\hline $\mathbf{T}_{5}$ & IBA $1500+N A A 1000 p p m$ & 1.86 & 2.10 & 6.75 & 5.46 & 8.33 \\
\hline$T_{6}$ & IBA $1500+N A A 2000 p p m$ & 1.22 & 1.85 & 5.97 & 4.98 & 7.92 \\
\hline $\mathbf{T}_{7}$ & IBA $3000+N A A 1000 p p m$ & 2.84 & 3.17 & 7.83 & 6.21 & 6.74 \\
\hline $\mathrm{T}_{8}$ & IBA $3000+N A A 2000 p p m$ & 2.31 & 2.83 & 7.24 & 5.87 & 6.15 \\
\hline $\mathrm{T}_{9}$ & Control & 0.00 & 0.00 & 0.00 & 0.00 & 0.00 \\
\hline & S.E. $(\mathbf{m}) \pm$ & 0.10 & 0.12 & 0.26 & 0.27 & 0.24 \\
\hline & $\mathrm{CD}_{(\mathrm{P}=0.05)}$ & 0.29 & 0.36 & 0.77 & 0.81 & 0.73 \\
\hline & CV $(\%)$ & 6.24 & 6.66 & 6.28 & 8.05 & 5.24 \\
\hline
\end{tabular}

Table.4 Effect of different treatments on number of roots/cuttings at 45 days

\begin{tabular}{|c|c|c|c|c|c|c|}
\hline \multicolumn{2}{|c|}{ Treatments } & \multirow{2}{*}{$\begin{array}{c}\text { Pratap } \\
4.70\end{array}$} & \multirow{2}{*}{$\begin{array}{c}\text { Prabhat } \\
4.17\end{array}$} & \multirow{2}{*}{$\begin{array}{c}\text { Shan-e- } \\
\text { Punjab } \\
11.63\end{array}$} & \multirow{2}{*}{$\begin{array}{c}\begin{array}{c}\text { Florda } \\
\text { Prince }\end{array} \\
10.10 \\
\end{array}$} & \multirow{2}{*}{$\begin{array}{c}\begin{array}{c}\text { Early } \\
\text { Grande }\end{array} \\
12.62 \\
\end{array}$} \\
\hline$T_{1}$ & IBA $1500 p p m$ & & & & & \\
\hline $\mathbf{T}_{2}$ & IBA 3000ppm & 5.00 & 4.50 & 12.00 & 10.60 & 13.00 \\
\hline $\mathbf{T}_{3}$ & NAA 1000ppm & 4.00 & 3.50 & 10.83 & 9.20 & 12.15 \\
\hline $\mathrm{T}_{4}$ & NAA 2000ppm & 4.40 & 3.80 & 11.27 & 9.60 & 11.65 \\
\hline$T_{5}$ & IBA $1500+N A A 1000 p p m$ & 3.00 & 2.10 & 8.50 & 7.90 & 10.20 \\
\hline$T_{6}$ & IBA 1500+NAA 2000ppm & 2.60 & 1.70 & 8.10 & 7.40 & 9.65 \\
\hline $\mathrm{T}_{7}$ & IBA 3000+NAA 1000ppm & 3.60 & 2.90 & 9.70 & 8.80 & 11.20 \\
\hline $\mathbf{T}_{8}$ & IBA 3000+NAA 2000ppm & 3.30 & 2.50 & 9.20 & 8.40 & 10.85 \\
\hline $\mathbf{T}_{9}$ & Control & 0.00 & 0.00 & 0.00 & 0.00 & 0.00 \\
\hline \multicolumn{2}{|c|}{ S.E.(m) \pm} & 0.15 & 0.11 & 0.14 & 0.18 & 0.09 \\
\hline \multicolumn{2}{|c|}{$\mathrm{CD}_{(\mathrm{P}=0.05)}$} & 0.45 & 0.32 & 0.42 & 0.53 & 0.26 \\
\hline \multicolumn{2}{|r|}{$\mathrm{CV}(\%)$} & 7.67 & 6.53 & 2.71 & 3.85 & 1.48 \\
\hline
\end{tabular}

Table.5 Effect of different treatments on root fresh weight (g) of cuttings at 45 days

\begin{tabular}{|c|c|c|c|c|c|c|}
\hline \multicolumn{2}{|r|}{ Treatments } & Pratap & Prabhat & Shan-e-Punjab & Florda Prince & Early Grande \\
\hline $\mathbf{T}_{1}$ & IBA 1500ppm & 0.46 & 0.51 & 0.64 & 0.56 & 0.71 \\
\hline$\overline{T_{2}}$ & IBA 3000ppm & 0.50 & 0.55 & 0.67 & 0.60 & 0.75 \\
\hline$\overline{\mathbf{T}_{3}}$ & NAA 1000ppm & 0.39 & 0.45 & 0.57 & 0.49 & 0.65 \\
\hline$\overline{\mathbf{T}_{4}}$ & NAA 2000ppm & 0.43 & 0.48 & 0.60 & 0.52 & 0.68 \\
\hline$\overline{T_{5}}$ & IBA $1500+N A A 1000 p p m$ & 0.25 & 0.35 & 0.48 & 0.38 & 0.51 \\
\hline$T_{6}$ & IBA $1500+N A A 2000 p p m$ & 0.20 & 0.31 & 0.45 & 0.34 & 0.47 \\
\hline $\mathbf{T}_{7}$ & IBA $3000+\mathrm{NAA} 1000 \mathrm{ppm}$ & 0.34 & 0.41 & 0.54 & 0.45 & 0.58 \\
\hline $\mathrm{T}_{8}$ & IBA 3000+NAA 2000ppm & 0.30 & 0.38 & 0.51 & 0.41 & 0.54 \\
\hline$T_{9}$ & Control & 0.00 & 0.00 & 0.00 & 0.00 & 0.00 \\
\hline & S.E.(m) \pm & 0.01 & 0.01 & 0.02 & 0.01 & 0.02 \\
\hline & $\mathrm{CD}_{(\mathrm{P}=0.05)}$ & 0.03 & 0.04 & 0.06 & 0.04 & 0.07 \\
\hline & $\mathrm{CV}(\%)$ & 5.53 & 5.58 & 6.66 & 5.00 & 6.93 \\
\hline
\end{tabular}


Table.6 Effect of different treatments on root dry weight (mg) of cuttings at 45 days

\begin{tabular}{|c|c|c|c|c|c|c|}
\hline \multicolumn{2}{|r|}{ Treatments } & \multirow{2}{*}{$\begin{array}{l}\text { Pratap } \\
5.39\end{array}$} & \multirow{2}{*}{$\begin{array}{l}\text { Prabhat } \\
5.19\end{array}$} & \multirow{2}{*}{$\begin{array}{c}\text { Shan-e- } \\
\text { Punjab } \\
6.21\end{array}$} & \multirow{2}{*}{$\begin{array}{c}\text { Florda } \\
\text { Prince } \\
6.02\end{array}$} & \multirow{2}{*}{$\begin{array}{c}\text { Early } \\
\text { Grande } \\
6.74\end{array}$} \\
\hline $\mathbf{T}_{1}$ & IBA $1500 p p m$ & & & & & \\
\hline $\mathbf{T}_{2}$ & IBA 3000ppm & 5.56 & 5.32 & 6.40 & 6.29 & 6.90 \\
\hline $\mathbf{T}_{3}$ & NAA $1000 p p m$ & 5.09 & 4.78 & 5.73 & 5.76 & 6.43 \\
\hline$\overline{T_{4}}$ & NAA 2000ppm & 5.23 & 4.98 & 5.98 & 5.87 & 6.66 \\
\hline $\mathbf{T}_{5}$ & IBA $1500+N A A$ 1000ppm & 4.38 & 4.34 & 5.21 & 5.19 & 5.51 \\
\hline$T_{6}$ & IBA $1500+N A A 2000 p p m$ & 4.17 & 4.12 & 5.09 & 4.87 & 5.32 \\
\hline$T_{7}$ & IBA $3000+N A A$ 1000ppm & 4.87 & 4.56 & 5.52 & 5.43 & 5.98 \\
\hline $\mathrm{T}_{8}$ & IBA 3000+NAA 2000ppm & 4.65 & 4.43 & 5.34 & 5.30 & 5.76 \\
\hline $\mathrm{T}_{9}$ & Control & 0.00 & 0.00 & 0.00 & 0.00 & 0.00 \\
\hline & S.E. $(\mathrm{m}) \pm$ & 0.11 & 0.10 & 0.12 & 0.10 & 0.11 \\
\hline & $\mathrm{CD}_{(\mathrm{P}=0.05)}$ & 0.32 & 0.31 & 0.36 & 0.29 & 0.33 \\
\hline & $\mathrm{CV}(\%)$ & 4.26 & 4.21 & 4.07 & 3.35 & 3.50 \\
\hline
\end{tabular}

According to Hartmann et al., (2002), IBA is the best auxin for general use because it is nontoxic to plants over a wide concentration range than NAA, and is effective in promoting rooting of a large number of plant species.

Highest root length $(9.48 \mathrm{~cm})$, root thickness $(3.08 \mathrm{~mm})$, length of main root $(11.25 \mathrm{~cm})$, and root weight $(0.75 \mathrm{~g}$ fresh wt. and $6.90 \mathrm{mg}$ dry wt.) recorded in Early Grande treated with IBA-3000 ppm. Maximum root length and length of main root of explants may be due to IBA which promotes the cell elongation that helped in increase in root length. IBA helps in mobilizing reserved food material, elongation of meristematic cells and differentiation of cambial initials into root primordia (Nanda, 1975). Increase in root length in cuttings treated with IBA is due to the enhanced hydrolysis of carbohydrates, synthesis of new proteins, cell enlargement and cell division induced by the auxins was reported by Strydem and Hartman, (1960). Another possible reason may be due to the early formation of roots and more utilization of reserved food materials of the treated cuttings (Ghatnatti, 1997). These results are similar to the findings of Tajbakhsh et al., (2009) in apple cuttings, Sharma et al., (1991) in guava,
Bal et al., (2000) in Plum, Mirabdulbaghi et al., (2011) in natural plum- apricot hybrid, Ahmed et al., (2003) in peach rootstock, and Galavi et al., (2013) in grape cuttings.

The increase in root thickness may be due to more vegetative growth and accumulation of carbohydrates. Root thickness is increased due to the effect of IBA as it increases cell wall plasticity and cell division, stimulates callus development and root growth (Weaver, 1972). These results are similar to the findings of Bal et al., (2000) in Plum, AlObeed (2000) in guava stem cuttings.

The increase in root weight is due to more number of roots, highest root thickness and length of the roots. IBA helps in mobilizing reserved food material, elongation of meristematic cells and differentiation of cambial initials into root primordia (Nanda, 1975). The increase in root weight may also be due to higher accumulation of photosynthates, metabolites and nutrients when treated with IBA. This result is in agreement with the observation of Damar et al., (2014) in Pomegranate cuttings. PGRs cause initial meristematic activity and stimulate the growth and development of the formed roots (Hartman et al., 2011). 
Transferring rizocalines and combined compound improve rooting indices such as fresh weight (Hartman et al., 2011). In the present study, the use of auxin improved root fresh weight $(\mathrm{g})$. The increase in number of roots and length of roots has directly influenced the fresh weight of roots. The increase in fresh weight may be due to enhanced tissue sensitivity and increased rooting via increased internal free auxin (Ingle, 2008). The higher fresh weight of roots may be attributed to the increased number of roots and roots length (Ingle and Venugopal, 2009). The results indicated that auxin improves dry weight of root and that higher IBA concentration results in higher root dry weight. At the same time with stimulation of rooting by auxin, the mobilization of carbohydrates from the leaves to the root helps rooting greatly increasing dry weight (Fathi and Ismaelpour, 2000). The results of the present studies are in agreement with the findings of Rufato and Kersten (2000) in Esmeralda Peach, Swedan et al., (1993) in hardwood cuttings of plum, peach and GF677 peach rootstock, Tajbakhsh et al., (2009) and Iqbal et al., (1999) in apple cuttings, Sharma et al., (1991) in guava, Bal et al., (2000) in Plum, Ahmed et al., (2010), Mirabdulbaghi et al., (2011) in natural plumapricot hybrid, Ahmed et al., (2003) in peach rootstock, Galavi et al., (2013) in grape cuttings and Maghsudlu et al., (2013) in Olive cuttings.

\section{References}

Ahmed, A. K., Amanullah, S. K., Basharat, H. S., Munir, A. K. (2010). Effect of indole butyric acid (IBA) on rooting of olive stem cuttings. Pakistan J. Agr. Res., Vol. 23 (3/4). 91-93.

Ahmed, M. S., Abbasi, N. A. and Amer, M. (2003). Effects of IBA on hardwood cuttings of Peach rootstocks under greenhouse conditions. Asian Journal of Plant Sciences. Vol. 2. 265-269.

Al-Obeed, R. S. (2000). The effect of growth regulators, phenolic compounds and time of propagation on the rooting of guava stem cuttings. Alex. J. Agric. Res. Vol. 45(2). 189199.

Bal, J. S. and Sandhawalia, S. S. (2000). Studies on propagation of subtropical Plum. Acta Hortic. Vol. 17. 17.

Damar, D., Barholia, A. K, Lekhi, R. and Haldar, A. (2014). Effect of growth regulators and biofertilizers on survival of Pomegranate (Punica granatum 1.) stem cuttings. Plant Archives. Vol. 14(1). 347-350.

Davis, T. D. and Haissig, B. E. (1990). Chemical control of adventitious root formation in cuttings. Plant Growth Reg. Soc. Amer. Quart. Vol. 18(1). 117.

De Klerk, G. J., van der Krieken, W. and De Jong, J. C. (1999). The formation of adventitious roots: new concepts, new possibilities. In vitro Cell. Dev. Biol. Plant. Vol. 35. 189-199.

Denny, C. and Arnold, A., (2001). Interactions among rooting substrate, phenological stage of cuttings and auxin concentration on the rooting of Cotinus obovatus. J. Appl. Hort. Vol. 1. 13-16.

Erdoan, V. and Aygün, A., (2006). A study on propagation of mulberry (Morus nigra L.) by softwood cuttings. II. National Berry Fruit Symposium, Tokat. pp. 172-175.

Fathi, G. H. and Ismaeilpour, B. (2000). Plant growth regulators: Principles and practice (Translation). Mashhad University Press, 288.

Galavi, M., Karimian, M. A. and Mousavi, S. R. (2013). Effects of different auxin (IBA) concentrations and plantingbeds on rooting grape cuttings (Vitis 
vinifera). Annual Review and Research in Biology. Vol. 3(4). 517523.

Ghatnatti, S. A. (1997). Stuides on propagation of Duranta plumeri Jacq. Var. Goldiana by stem cuttings with growth regulators under mist. M.Sc.(Agri.) Thesis. University of Agricultural Sciences. Dharwad.

Hartmann, H. T., Kester, D. E., Davies, F. T. T. and Geneve, R. L. (2011). Plant propagation, principles and practices, 8th ed. Prentice-Hall, Upper Saddlr River, New Jersey. 915.

Hartmann, H.T. and Kester, D.E. (1983). Plant Propagation, Principles and Practices Fourth Ed., Prentice- Hill, INC Engleood Cliffs, New Jersy, USA.

Hartmann, H.T. and Kester, D.E. (1990). Plant Propagation, Principles and Practices Fifth Ed., Prentice- Hill, INC Engleood Cliffs, New Jersy, USA.

Ingle, M. R. (2008). Effect of growth regulators and environments on rooting of Stevia cuttings (Stevia rebaudiana Bertoni). Univ Agri Sci Dharwad, MSc Thesis.

Ingle, M. R. and Venugopal, C. K. (2009). Effect of different growth regulators on rooting of stevia (Stevia rebaudiana Bertoni) cuttings. Karnataka J Agri Sci. Vol. 22(2). 460-461.

Iqbal, M., Subhan, F., Ghafoor, A., Waseem, K. and Jilani, M.S. (1999). Effect of different concentrations of indole butyric Acid (IBA) on root initiation and plant survival of apple cuttings. Pakistan Journal Biological Sciences. Vol. 2. 1314-1316.

Leopold, A. C. (1995). Auxins and plant growth substances. Berkeley and Los Angeles. Univ. California Press, California. Pp. 372-377.

Ludwig-Müller, J. (2000). Indole-3-butyric acid in plant growth and development.
Plant Growth Regul. Vol. 32. 219230.

Maghsudlu, M., Afshari, H. and Faraji, A. (2013). The evaluation of the effect of different iba (indole-3-butyric acid) hormone concentration and different kinds of cutting on rooting of two compatible Olive cultivars cuttings in Golestan province. Bull. Env. Pharmacol. Life Sci. Vol. 2(6). 82- 88.

Mirabdulbaghi, M., Zarghami, R. and Azghandi, A.V. (2011). Propagation of Tanasgol, A Natural Plum-Apricot Hybrid (Prunus domestica-armenia) developed in Iran. Trends in Horticultural Research. Vol. 1(1). 2731.

Nanda, K. K. (1975). Physiology of adventitious root formation. Indian Journal of Plant Physiology. Vol. 18. $18-90$.

Riov, J. (1993). Endogenous and exogenous auxin conjugates in rooting of cuttings. Acta Hortic. Vol. 329. 284288.

Rufato, L. and Kersten, E. (2000). Rooting of cuttings of peaches (Prunus persica (L.) Batsch) cv. Esmeralda and BR2 exposed to stratification and indole butyric acid. Revista Brasileira de Fruiticultura. Vol. 22. 191-194.

Sharma, R. S., Ray, P. K. and Singh, B. K. (1991). Influence of growth regulators and time of operation on rooting of air layering in guvava. Orissa Journal Horticulture. Vol. 19. 41- 45.

Spethmann, W. and Hamzah, A. (1988). Growth hormone induced root system types in cuttings of some broad leaved tree species. Acta Hortic. Vol. 226. 601-605.

Strydem, D. K. and Hartman, H. T. (1960). Effect of indole butyric acid and respiration and nitrogen metabolism in Marianna 2624 plum softwood stem cuttings. Proceedings of American 
Society for Horticultural Science. Vol. 45(1-2). 81-82.

Swedan, A.A., Edriss, M.H., Alhamed, A., Yusre, A. (1993). Root initiation in the plum rootstock Marianna and the promotive effects of co-factors. Egyptian Journal of Horticulture. Vol. 20(1). 43-55.

Tajbakhsh, M., Korkan, M. and Ghiyasi, M. (2009). Effect of timing on callus formation and rooting ability in IBAtreated hardwood stem cutting of
Persian walnut, hazelnut and apple. Not. Bot. Hort. Agrobot. Cluj-Napoca. Vol. 37. 103-107.

Tworkoski, T., and Takeda, F., (2007). Rooting response of shoot cuttings from three peach growth habits. Scientia Horticulturae. Vol. 115. 98100.

Weaver, R. J. (1972). Plant Growth Substances in Agriculture. W.H. Freeman and Company. San Fransisco. 504.

\section{How to cite this article:}

Shashank Kumar, Samik Sengupta, Neha Nandan, Arun Kumar and Prem Prakash. 2018. Comparative Performance of Different Genotypes of Peach Based on Their Rooting Response of Hardwood Cuttings. Int.J.Curr.Microbiol.App.Sci. 7(05): 1587-1594.

doi: https://doi.org/10.20546/ijcmas.2018.705.188 